\title{
Aerosol dry deposition measured with eddy-covariance technique at Wasa and Aboa, Dronning Maud Land, Antarctica
}

\author{
Anna GRÖNLUnd, ${ }^{1}$ Douglas NILSSON,,${ }^{1}$ Ismo K. KOPONEN, ${ }^{2}$ Aki VIRKKULA, ${ }^{3}$ \\ Margareta E. HANSSON ${ }^{4}$ \\ ${ }^{1}$ Department of Meteorology, Stockholm University, S-106 91 Stockholm, Sweden \\ ${ }^{2}$ Department of Physics, University of Helsinki, FIN-00014 Helsinki, Finland \\ ${ }^{3}$ Finnish Meteorological Institute, FIN-00880 Helsinki, Finland \\ ${ }^{4}$ Department of Physical Geography and Quaternary Geology, Stockholm University, S-106 91 Stockholm, Sweden \\ E-mail: margareta.hansson@natgeo.su.se
}

\begin{abstract}
Interpretation of ice-core records in terms of changes in atmospheric concentrations requires understanding of the various parameters within air-snow transfer functions. The dry-deposition velocity is one of these parameters, dependent on local meteorological conditions and thereby also affected by climate changes. We have determined aerosol dry-deposition velocities by measurements of aerosol particle-number concentration and the vertical wind component with an eddy-covariance system close to the Swedish and Finnish research stations Wasa and Aboa in Dronning Maud Land, Antarctica. Measurements were performed over a smooth, snow-covered area and over moderately rough, rocky ground during 4 and 19 days, respectively, in January 2000. The median dry-deposition velocity determined $5.25 \mathrm{~m}$ above the surface was 0.33 and $0.80 \mathrm{~cm} \mathrm{~s}^{-1}$, respectively. The large difference between the two sites was mainly due to the stratification of the surface boundary layer, the surface albedo and the surface roughness height. The dry-deposition number fluxes were dominated by the particle-size modes defined as ultrafine and Aitken, with mean diameters around 14 and $42 \mathrm{~nm}$, respectively. A larger dry-deposition velocity, owing to stronger Brownian diffusion, for the smaller ultrafine mode was verified by the measurements.
\end{abstract}

\section{INTRODUGTION}

Wet, dry and fog deposition are the mechanisms by which particles and gases are removed from the atmosphere (e.g. Davidson and others, 1996). If the deposition takes place on the cold ice sheets of Antarctica and Greenland, the chemical constituents are embedded in the glacial ice when more snow accumulates on top of the previous layer, and records of deposition over time are preserved. Many deposition records have been extracted from polar ice sheets and have contributed much to our present understanding of changes in atmospheric composition in the past (e.g. Barnola and others, 1987; Legrand and others, 1988; Hansson, 1994; Steffensen, 1997; Fuhrer and others, 1999). However, interpretation of ice-core deposition records spanning large climatic changes requires understanding of the various parameters within the air-snow transfer functions. The dry-deposition velocity is one of these parameters and it is dependent on local meteorological conditions and thereby also affected by climate changes. The drydeposition velocity is strongly size-dependent (Davidson and others, 1996), with a clear minimum for particles about $0.1 \mu \mathrm{m}$ in diameter (i.e. accumulation mode). Larger particles have higher dry-deposition velocities due to sedimentation and impaction processes, and so have the smaller particles due to Brownian diffusion. Particles with higher dry-deposition velocity will therefore be over-represented in the deposition records in the ice compared to the atmospheric concentrations (Unnerstad and Hansson, 2001).

Previously reported data on dry-deposition velocities over snow surfaces are sparse and highly varying between differ- ent species (e.g. Ibrahim and others, 1983; Cadle and others, 1985; Davidson and others, 1985; Hillamo and others, 1993; Bergin and others 1995). Impurities in ice cores are usually measured in the soluble phase (as ion concentrations) or in the insoluble phase (as elemental concentrations, or as total dust mass or number concentrations). These two fractions are combined in the atmosphere, either internally or externally mixed, but most probably interacting and determining the aerosol particle-size distribution together.

The aim of this study was to characterize dry deposition of aerosol particles to surfaces in Antarctica in relation to surface roughness, turbulent flow, boundary-layer structure and the aerosol number and size distribution. An eddy-covariance (EG) method was used which offered a way to measure the turbulent transport (vertical flux) of a compound by correlating the fast fluctuations of its number concentrations with the vertical wind speed. This method has previously been successfully applied with a similar instrumentation in the Arctic over sea and pack ice (Nilsson and Rannik, 2001) and over a Scots pine forest in southern Finland (Buzorius and others, 1998, 2000).

\section{MEASUREMENTS AND METHODS}

\section{Sites}

The Swedish station Wasa and the Finnish station Aboa in Dronning Maud Land (DML), Antarctica, are situated on the nunatak Basen $\left(73^{\circ} 03^{\prime} \mathrm{S}, 13^{\circ} 25^{\prime} \mathrm{W}\right)$. Basen lies in the northeastern part of Vestfjella, which is a $135 \mathrm{~km}$ long range 
of nunataks. The mountain range is almost parallel to the coast and located about $120 \mathrm{~km}$ from the coast. Basen reaches $584 \mathrm{~m}$ a.s.l.

The EC measurements in January 2000 were made at two different sites, Lilla Vardet and Aerosol Hill, over periods of 4 and 19 days, respectively. Lilla Vardet is situated $1 \mathrm{~km}$ east of the research stations, and the measurements were performed over a smooth snow surface that had a considerable fetch over snow in the main wind direction (i.e. east-northeast). The footprint of the EC system consisted entirely of a snowcovered area. Aerosol Hill is located a few hundred metres east-northeast of the research stations, and the ground on which the EC system was standing consists mainly of rocks in the $5-20 \mathrm{~cm}$ diameter range. The footprint of the EC system at Aerosol Hill was dominated by a rocky surface interrupted by snow patches.

\section{The EG flux system}

A Gill Solent 1012R research model ultrasonic anemometer was mounted at $5.25 \mathrm{~m}$ above the ground on a mast. A TSI 3010 Condensation Particle Counter (CPG) was located in an isolated aluminium box at the foot of the mast, with its sampling intake located just below the sensing heads of the ultrasonic anemometer. The box also contained a heating system together with a computer and an interface to the ultrasonic anemometer. The sampling flow rate was $1 \mathrm{~L} \mathrm{~min}^{-1}$ through a $7.8 \mathrm{~m}$ heated stainless-steel sampling tube with an inner diameter of $4 \mathrm{~mm}$.

The anemometer measured the vertical wind component $(w)$ together with temperature $(T)$ and the horizontal wind components $(u$ and $v$ ) at $20.8 \mathrm{~Hz}$. The CPC measured the number concentration $(N)$ of aerosol particles with a dry diameter $\left(D_{\mathrm{p}}\right)$ larger than $10 \mathrm{~nm}$. The maximum concentration that this device could measure was 10000 particles $\mathrm{cm}^{-3}$.

\section{EC flux calculations}

The fast measurements by the system allow us to separate $\mathcal{N}$ and $w$ into mean values $\langle N\rangle$ and $\langle w\rangle$ (resulting from the mean flow defined by a 120 s running average) and turbulent fluctuations $N^{\prime}$ and $w^{\prime}$ :

$$
\begin{aligned}
& N=\langle N\rangle+N^{\prime} \\
& w=\langle w\rangle+w^{\prime} .
\end{aligned}
$$

The aerosol flux as well as momentum and turbulent sensibleheat fluxes were calculated following Buzorius and others (1998) and Nilsson and Rannik (2001). A three-dimensional co-ordination of wind vector to the local streamlines was performed according to Kaimal and Finnigan (1994). The turbulent vertical aerosol number flux $(F)$ is given by

$$
F=\left\langle N^{\prime} w^{\prime}\right\rangle \text {, }
$$

where the covariance $\left\langle N^{\prime} w^{\prime}\right\rangle$ was calculated over $30 \mathrm{~min}$ periods from the turbulent fluctuations $N^{\prime}$ and $w^{\prime}$. By convention, a positive value for $F$ implies an upward flux. The aerosol deposition velocity $\left(v_{\mathrm{d}}\right)$ was calculated from the measured flux normalized by the mean aerosol number concentration at a certain reference height:

$$
v_{\mathrm{d}}=-\frac{F}{\langle N\rangle} \text {. }
$$

A positive deposition velocity is defined as being downwards. The response time of the CPC was of the order of $1 \mathrm{~Hz}$. The peak contribution to the aerosol flux will be at frequencies of $0.1 \mathrm{~Hz}$ or lower. The underestimation of particle-number flux due to the limited frequency response of the CPC was corrected for according to Moore (1986). The correction factor was typically $<10 \%$, since eddies at frequencies $>1 \mathrm{~Hz}$ are responsible for a relatively small part of the flux.

The momentum flux and friction velocity $\left(u_{*}\right)$ were calculated from $u, v$ and $w$, while the turbulent sensible-heat flux $(H)$ was calculated from $w$ and $T$. The Monin-Obukhov length $(L)$ was subsequently calculated from $u_{*}$ and $H$. The surface roughness height $\left(z_{0}\right)$ was solved numerically from:

$$
\begin{aligned}
& u_{*}= \\
& \left\{\begin{array}{c}
\frac{\langle U\rangle}{\frac{1}{\kappa}\left[\ln \left(\frac{z}{z_{0}}\right)+4.7\left(\frac{z}{L}-\frac{z_{0}}{L}\right)\right]} ; \quad \frac{z}{L} \geq 0 \text { (stable) } \\
\frac{\frac{1}{\kappa}\left[\ln \left(\frac{z}{z_{0}}\right)+\ln \left(\frac{\left(\phi_{0}^{2}+1\right)\left(\phi_{0}+1\right)^{2}}{\left(\phi^{2}+1\right)(\phi+1)^{2}}\right)+2\left(\tan ^{-1} \phi-\tan ^{-1} \phi_{0}\right)\right]}{\frac{z}{L} \leq 0(\text { unstable }),}
\end{array}\right.
\end{aligned}
$$

where $\kappa$ is von Kármán's constant $(\kappa=0.4),\langle U\rangle$ is the averaged wind speed, $z$ is the height of measurement, $\phi=(1-$ $15 z / L)^{1 / 4}$ and $\phi_{0}=\left(1-15 z_{0} / L\right)^{1 / 4}$.

\section{Differential-mobility particle sizer}

A differential-mobility particle sizer (DMPS) system at Aerosol Hill was continuously monitoring the aerosol particle-size distribution from 3 to $850 \mathrm{~nm}$ in diameter during the period 5-20 January 2000. The measured aerosol particle-number concentrations (for $D_{\mathrm{p}}>10 \mathrm{~nm}$ ) from the DMPS system agrees well with the CPC data from the EC measurements. We have utilized the DMPS data to separate the EC measurement data from Aerosol Hill into groups dominated by one of three particle-size modes - ultrafine, Aitken, or Aitken plus accumulation mode - and have thereby been able to identify dry-deposition velocities for the different particle-size modes. The results from the DMPS measurements will be reported extensively elsewhere (paper in preparation by I. K. Koponen).

\section{Dry-deposition velocity}

The dry-deposition velocity can also be expressed in terms of resistances (e.g. Seinfeld and Pandis, 1998):

$$
v_{\mathrm{d}}=\frac{1}{r_{\text {tot }}}=\frac{1}{r_{\mathrm{a}}+r_{\mathrm{b}}+r_{\mathrm{a}} r_{\mathrm{b}} v_{\mathrm{s}}}+v_{\mathrm{s}},
$$

where $r_{\mathrm{a}}$ is the aerodynamic resistance, $r_{\mathrm{b}}$ is the resistance in the quasi-laminar sub-layer and $v_{\mathrm{s}}$ is the settling velocity due to gravitation (e.g. Hinds, 1982).

The aerodynamic resistance is a function of $u_{*}, z_{0}, z$ and stability $(z / L)$. It can be expressed as (e.g. Seinfeld and Pandis, 1998):

$$
\begin{aligned}
& r_{\mathrm{a}}= \\
& \left\{\begin{aligned}
& \frac{1}{\kappa u_{*}} {\left[\ln \left(\frac{z}{z_{0}}\right)+4.7\left(\frac{z}{L}-\frac{z_{0}}{L}\right)\right] ; \quad \frac{z}{L} \geq 0 \text { (stable) } } \\
& \frac{1}{\kappa u_{*}}\left[\ln \left(\frac{z}{z_{0}}\right)+\ln \left(\frac{\left(\phi_{0}^{2}+1\right)\left(\phi_{0}+1\right)^{2}}{\left(\phi^{2}+1\right)(\phi+1)^{2}}\right)\right. \\
&\left.\quad+2\left(\tan ^{-1} \phi-\tan ^{-1} \phi_{0}\right)\right] ; \quad \frac{z}{L} \leq 0 \text { (unstable). }
\end{aligned}\right.
\end{aligned}
$$

The sub-layer resistance $r_{\mathrm{b}}$ is a function of $D_{\mathrm{p}}, z_{0}, u_{*}$, the diffusion coefficient $(D)$ and kinematic viscosity $(v)$. This 
Table 1. Measured and calculated variables at Lilla Vardet, given as arithmetic mean plus or minus $1 \sigma$, the median, the range where $90 \%$ of the data are found and the number of data points (0.5 hour averages)

\begin{tabular}{|c|c|c|c|c|c|c|c|c|}
\hline & $\begin{array}{c}v_{\mathrm{d}} \\
\mathrm{cm} \mathrm{s}^{-1}\end{array}$ & $\begin{array}{c}F \\
10^{6} \mathrm{~m}^{-2} \mathrm{~s}^{-1}\end{array}$ & $\begin{array}{c}F \downarrow \\
10^{6} \mathrm{~m}^{-2} \mathrm{~s}^{-1}\end{array}$ & $\begin{array}{c}F \uparrow \\
10^{6} \mathrm{~m}^{-2} \mathrm{~s}^{-1}\end{array}$ & $\begin{array}{l}z_{0} \\
\mathrm{~cm}\end{array}$ & $\begin{array}{c}U \\
\mathrm{~ms}^{-1}\end{array}$ & $z / L$ & $\begin{array}{c}u_{*} \\
\mathrm{~cm} \mathrm{~s}^{-1}\end{array}$ \\
\hline $\begin{array}{l}\text { Mean } \pm \sigma \\
\text { Median } \\
90 \% \text { range } \\
\text { Number }\end{array}$ & $\begin{array}{c}3.7 \pm 16.9 \\
0.33 \\
0.08 \text { to } 1.89 \\
38\end{array}$ & $\begin{array}{c}-12.3 \pm 103.9 \\
-0.06 \\
-4.53 \text { to } 2.49 \\
79\end{array}$ & $\begin{array}{c}-28.8 \pm 134.0 \\
-1.15 \\
-6.42 \text { to }-0.26 \\
38\end{array}$ & $\begin{array}{c}3.12 \pm 6.87 \\
0.98 \\
0.25 \text { to } 7.80 \\
41\end{array}$ & $\begin{array}{c}0.13 \pm 0.18 \\
0.03 \\
0.007 \text { to } 0.38 \\
17\end{array}$ & $\begin{array}{c}2.31 \pm 1.47 \\
2.08 \\
0.74 \text { to } 4.29 \\
79\end{array}$ & $\begin{array}{c}2.26 \pm 8.96 \\
-0.005 \\
-0.08 \text { to } 4.38 \\
79\end{array}$ & $\begin{array}{c}9.02 \pm 5.98 \\
7.5 \\
1.93 \text { to } 18.6 \\
45\end{array}$ \\
\hline
\end{tabular}

Table 2. Measured and calculated variables at Aerosol Hill, given as arithmetic mean plus or minus $1 \sigma$, the median, the range where $90 \%$ of the data are found and the number of data points (0.5 hour averages)

\begin{tabular}{|c|c|c|c|c|c|c|c|c|}
\hline & $\begin{array}{c}v_{d} \\
\mathrm{~cm} \mathrm{~s}^{-1}\end{array}$ & $\begin{array}{c}F \\
10^{6} \mathrm{~m}^{-2} \mathrm{~s}^{-1}\end{array}$ & $\begin{array}{c}F \downarrow \\
10^{6} \mathrm{~m}^{-2} \mathrm{~s}^{-1}\end{array}$ & $\begin{array}{c}F \uparrow \\
10^{6} \mathrm{~m}^{-2} \mathrm{~s}^{-1}\end{array}$ & $\begin{array}{l}z_{0} \\
\mathrm{~cm}\end{array}$ & $\begin{array}{c}U \\
\mathrm{~ms}^{-1}\end{array}$ & $z / L$ & $\begin{array}{c}u * \\
\mathrm{cms}^{-1}\end{array}$ \\
\hline $\begin{array}{l}\text { Mean } \pm \sigma \\
\text { Median } \\
90 \% \text { range } \\
\text { Number }\end{array}$ & $\begin{array}{c}1.86 \pm 10.0 \\
0.80 \\
0.2 \text { to } 2.4 \\
385\end{array}$ & $\begin{array}{c}-3.34 \pm 45.42 \\
-1.94 \\
-8.18 \text { to } 4.99 \\
584\end{array}$ & $\begin{array}{c}-9.17 \pm 52.71 \\
-3.33 \\
-11.88 \text { to }-0.92 \\
386\end{array}$ & $\begin{array}{c}8.03 \pm 21.86 \\
2.75 \\
0.82 \text { to } 13.27 \\
198\end{array}$ & $\begin{array}{c}0.21 \pm 0.22 \\
0.11 \\
0.02 \text { to } 0.58 \\
471\end{array}$ & $\begin{array}{c}5.88 \pm 3.04 \\
5.34 \\
2.60 \text { to } 9.23 \\
590\end{array}$ & $\begin{array}{c}-0.57 \pm 2.61 \\
-0.17 \\
-0.86 \text { to }-0.02 \\
579\end{array}$ & $\begin{array}{c}29.6 \pm 11.6 \\
29.0 \\
15.2 \text { to } 43.7 \\
582\end{array}$ \\
\hline
\end{tabular}

resistance increases with increasing surface roughness and decreasing diffusivity of the aerosol. For fine particles, the influence of Brownian diffusion increases, and $r_{\mathrm{b}}$ decreases with decreasing particle size. Schack and others (1985) give an expression for $r_{\mathrm{b}}$ for neutral conditions and a completely rough surface:

$$
r_{\mathrm{b}}=\left[A D^{2 / 3}\left(\frac{u_{*}}{z_{0}}\right)^{1 / 2} v^{-1 / 6}+B D_{\mathrm{p}}^{2}\left(\frac{u_{*}}{z_{0}}\right)^{2 / 3} v^{-1 / 2}\right]^{-1} .
$$

$A$ and $B$ are empirical constants of proportionality and depend on the shape of the elements composing the collecting surface. The right side of the equation is for the diffusion and interception ranges, respectively. The dry-deposition velocity is indirectly dependent on $\langle U\rangle, z / L$ and $z_{0}$ through the $u_{*}$ dependency of Equation (4).

\section{RESULTS AND DISGUSSION}

\section{Snow-covered area at Lilla Vardet}

The EC measurements at Lilla Vardet were performed during 4 days at the beginning ofJanuary, and the measured and calculated variables are shown in Table 1 . Both downward and upward particle fluxes were registered, but the downward flux was one order of magnitude larger on average. Ninety per cent of the aerosol particle-number concentrations were found in the range 307-444 particles $\mathrm{cm}^{-3}$. The stratification of the surface boundary layer was near neutral most of the time, as indicated by a median for $z / L$ of -0.005 . Ninety per cent of the dry-deposition velocities ranged from 0.08 to $1.89 \mathrm{~cm} \mathrm{~s}^{-1}$, with a median of $0.33 \mathrm{~cm} \mathrm{~s}^{-1}$, for all particle sizes $\left(D_{\mathrm{p}}>10 \mathrm{~nm}\right)$.

\section{Snow-free area at Aerosol Hill}

The EC measurements at Aerosol Hill were performed over a 19 day period later in January, and the measured and calculated variables are shown in Table 2. At Aerosol Hill the downward and upward particle fluxes were of the same order of magnitude, with a small net flux downwards. A frequency analysis showed that two-thirds of the measured particle fluxes were negative, which also indicates that deposition dominated. The positive fluxes, i.e. upward fluxes, may be explained as resuspension of particles from the ground. However, it should be noted that upward fluxes were also measured over the snow surface at Lilla Vardet. Particlenumber concentrations at Aerosol Hill were found in the range 270-750 particles $\mathrm{cm}^{-3}$. The low albedo of the nunatak on which the EC system stood favours unstable conditions in the surface boundary layer. This is indicated by the negative values for $z / L$ in $90 \%$ of cases. An explanation for this is the relatively large net radiation, which at noon peaked at approximately $90 \mathrm{~W} \mathrm{~m}^{-2}$. The average wind speed for the different measuring periods was higher at Aerosol Hill than at Lilla Vardet, and reached $>10 \mathrm{~m} \mathrm{~s}^{-1}$ during $8 \%$ of the measuring period. Ninety per cent of the dry-deposition velocities ranged from 0.2 to $2.4 \mathrm{~cm} \mathrm{~s}^{-1}$, with a median of $0.80 \mathrm{~cm} \mathrm{~s}^{-1}$, for all particle sizes $\left(D_{\mathrm{p}}>10 \mathrm{~nm}\right)$.

\section{Diurnal cycles}

Figure 1 shows 0.5 hour averages in meteorological variables from the period of measurement at Aerosol Hill. The turbulent sensible-heat flux (Fig. la) had a diurnal cycle that peaked at noon when the solar zenith angle was at minimum, with an average $H$ maximum of $260 \mathrm{~W} \mathrm{~m}^{-2}$. The temperature cycle (Fig. lb) lagged the $H$ cycle by about 2 hours, and the average diurnal temperature variation ranged from $-6.6^{\circ}$ to $-3.7^{\circ} \mathrm{C}$. During the morning hours, the surface boundary layer was close to neutrally stratified, but an unstable boundary layer was formed during the day due to the radiative warming at the surface (Fig. 1c). When the wind speed increased during the day (Fig. ld) and the stability diminished, the friction velocity increased (Fig. le). The particle concentration increased rapidly during the morning hours 

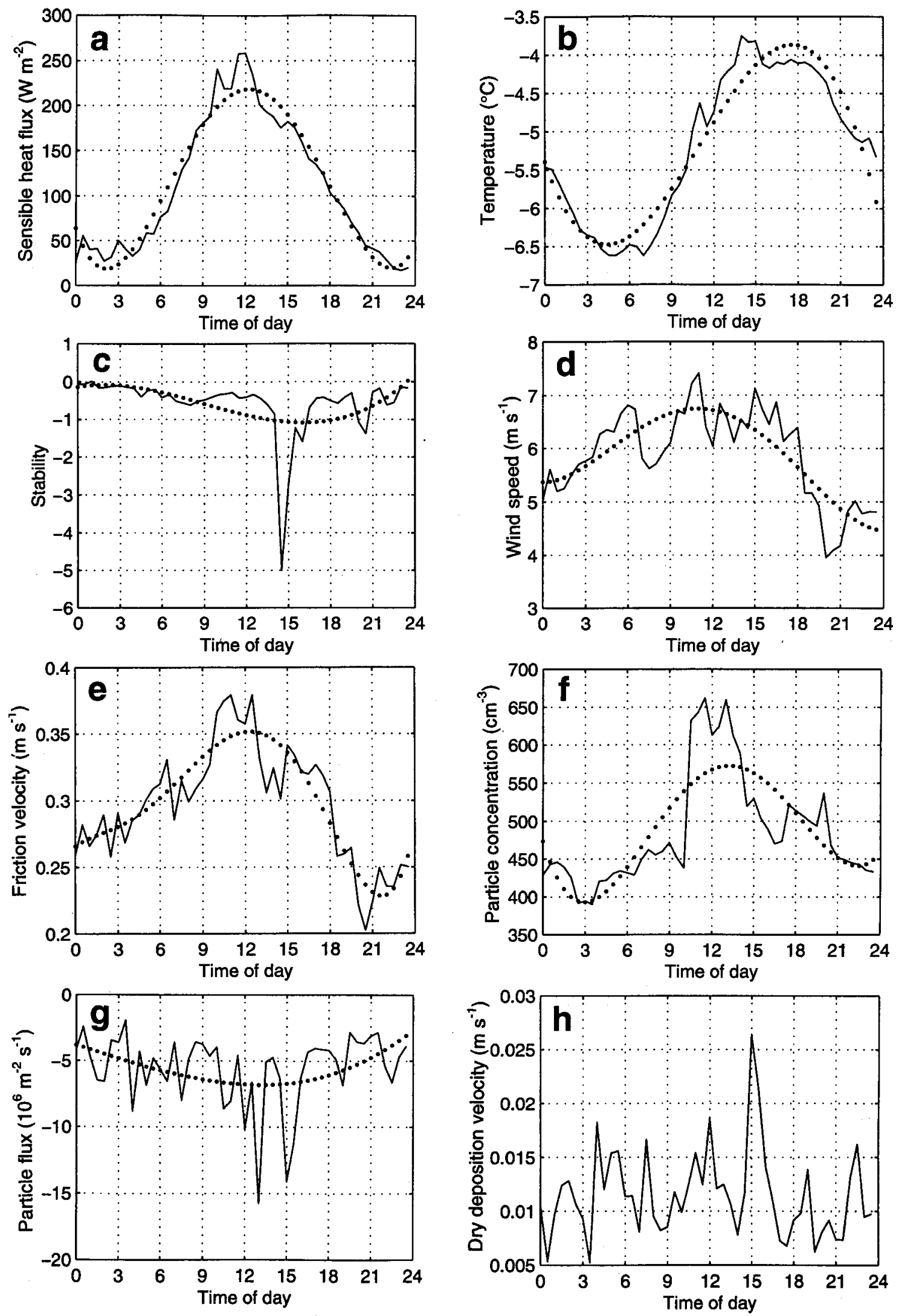

Fig. 1. Averaged diurnal cycles at Aerosol Hill of (a) turbulent sensible-heat flux ( $H)$, (b) temperature (T), (c) surface boundary-layer stability $(z / L),(d)$ wind speed $(U),\left(\right.$ e) friction velocity $\left(u_{*}\right),(f)$ particle-number concentration $(\mathcal{N}),(g)$ particle flux $(F)$ and $(h)$ dry-deposition velocity $\left(v_{\mathrm{d}}\right)$. Full lines connect 0.5 hour averages, and dotted lines are polynomials fitted to the diurnal averages.

and culminated at noon (Fig. lf). A similar but more scattered trend was seen in the downward aerosol particle flux (Fig. lg).

Hence, we can see a clear diurnal cycle in the surface boundary-layer stability, temperature and fluxes. This is not due to the contrast between night and day, since we had sunlight 24 hours $^{-1}$. Instead, the driving force must be the diurnal cycle in the solar zenith angle, which is still rather large at $73^{\circ} \mathrm{S}$. This agrees with the measurements by Nilsson and Rannik (2001) over the pack ice of the Arctic Ocean, although the diurnal amplitudes were smaller in 
Table 3. Examples of dry-deposition velocities $( \pm 1 \sigma)$ to snow surfaces

Species $v_{\mathrm{d}}$

Condition or site

$\mathrm{cm} \mathrm{s}^{-1}$

\begin{tabular}{|c|c|c|}
\hline $\mathrm{SO}_{4}{ }^{2-}$ & 0.039 & Stable atmosphere, $D_{\mathrm{p}}=0.7 \mu \mathrm{m}^{1}$ \\
\hline $\mathrm{SO}_{4}{ }^{2-}$ & 0.096 & Unstable atmosphere, $D_{\mathrm{p}}=0.7 \mu \mathrm{m}^{1}$ \\
\hline $\mathrm{Al}$ & $0.2 \pm 0.06$ & Dye 3 , Greenland ${ }^{2}$ \\
\hline $\mathrm{Fe}$ & $0.6 \pm 0.09$ & Dye 3 , Greenland ${ }^{2}$ \\
\hline $\mathrm{K}$ & $0.05 \pm 0.02$ & Dye 3 , Greenland ${ }^{2}$ \\
\hline $\mathrm{Mg}$ & $0.2 \pm 0.06$ & Dye 3 , Greenland ${ }^{2}$ \\
\hline $\mathrm{Mn}$ & $0.3 \pm 0.1$ & Dye 3 , Greenland ${ }^{2}$ \\
\hline $\mathrm{Na}$ & $0.2 \pm 0.02$ & Dye 3 , Greenland ${ }^{2}$ \\
\hline S & $0.02 \pm 0.01$ & Dye 3 , Greenland ${ }^{3}$ \\
\hline $\mathrm{Ca}$ & $0.35 \pm 0.16$ & Dye 3, Greenland $^{3}$ \\
\hline $\mathrm{K}$ & $0.17 \pm 0.12$ & Dye 3 , Greenland ${ }^{3}$ \\
\hline $\mathrm{Mg}$ & $0.70 \pm 0.95$ & Dye 3 , Greenland ${ }^{3}$ \\
\hline $\mathrm{Na}$ & $0.16 \pm 0.12$ & Dye 3 , Greenland ${ }^{3}$ \\
\hline $\mathrm{S}$ & $0.022 \pm 0.016$ & Dye 3, Greenland ${ }^{4}$ \\
\hline $\mathrm{Ca}$ & $0.11 \pm 0.021$ & Dye 3, Greenland ${ }^{4}$ \\
\hline $\mathrm{K}$ & $0.064 \pm 0.017$ & Dye 3, Greenland ${ }^{4}$ \\
\hline $\mathrm{Mg}$ & $0.078 \pm 0.016$ & Dye 3, Greenland ${ }^{4}$ \\
\hline $\mathrm{Na}$ & $0.067 \pm 0.015$ & Dye 3 , Greenland ${ }^{4}$ \\
\hline MSA & $0.024 \pm 0.023$ & Summit, Greenland ${ }^{4}$ \\
\hline $\mathrm{SO}_{4}{ }^{2-}$ & $0.021 \pm 0.017$ & Summit, Greenland ${ }^{4}$ \\
\hline $\mathrm{NO}_{3}^{-}$ & $0.073 \pm 0.053$ & Summit, Greenland ${ }^{4}$ \\
\hline $\mathrm{NH}_{4}^{+}$ & $0.017 \pm 0.011$ & Summit, Greenland ${ }^{4}$ \\
\hline
\end{tabular}

${ }^{1}$ Ibrahim and others (1983).

${ }^{2}$ Davidson and others (1985).

${ }^{3}$ Hillamo and others (1993).

${ }^{4}$ Bergin and others (1995).

their case due to the higher latitude $\left(>80^{\circ} \mathrm{N}\right)$. The drydeposition velocity, or normalized flux, had no significant trend (Fig. 1h). Since most of the large downward fluxes occurred simultaneously with high values of aerosol particle concentrations, the value of the normalized flux remains practically the same when data points are compared.

Because the measurements over the snowfield at Lilla Vardet lasted only a few days, the average diurnal cycles are much too influenced by the weather conditions on individual days to produce a figure corresponding to Figure 1. However, the data from Lilla Vardet indicate a diurnal behaviour similar to that for Aerosol Hill, with some differences. At Lilla Vardet, $H$ was negative at "night" and positive at noon, with a smaller amplitude of the diurnal cycle. This is in agreement with a more stably stratified surface boundary layer and obviously caused by the higher albedo of the snowfield and the smaller absorption of solar radiation as compared to Aerosol Hill. The downward aerosol fluxes and the dry-deposition velocity over the snowfield were smaller than at Aerosol Hill, except in the afternoons.

\section{Dry-deposition velocities}

Previously reported dry-deposition velocities show a large variability depending on the atmospheric conditions and characteristics of the deposited species. Examples of dry-deposition velocities for different species to snow surfaces on Greenland are shown in Table 3. None of these studies were made with the EG method. All these previous studies emphasized the dry-deposition velocity for the size range that is most important for mass deposition, rather than number deposition, hence they refer to a larger size range. The dry-deposition velocities in this study are generally higher than the values in Table 3,

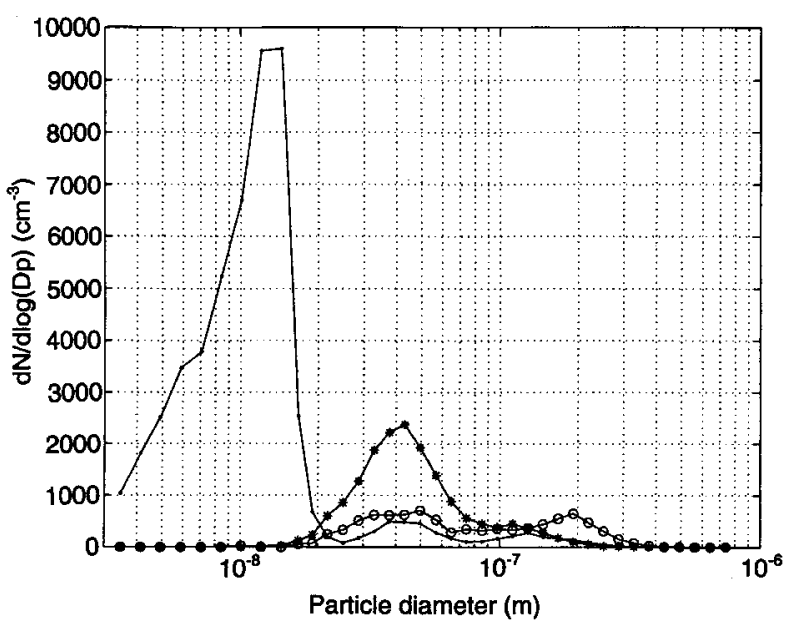

Fig. 2. Three examples of particle-number size distributions, $\mathrm{d} N / \mathrm{d} \log \left(D_{\mathrm{p}}\right)$, showing the three categories into which the EC dataset was divided: ultrafine mode (solid line), Aitken mode (solid line with stars) and Aitken plus accumulation mode (solid line with circles).

especially the ones measured over the snow-free surface at Aerosol Hill. However, an order-of-magnitude difference is found in the reported values for $\mathrm{K}, \mathrm{Mg}$ and $\mathrm{Na}$ from Dye 3, hence the absolute value of the dry-deposition velocity can vary strongly between different situations.

The dry-deposition velocity is dependent on the turbulence intensity, atmospheric stability and particle size (see Equations (5-7)). Unlike Nilsson and Rannik (2001), we were unable to identify an increased dry-deposition velocity with increased friction velocity in this dataset. The reason is probably a large scatter in $v_{\mathrm{d}}$ due to changes in the aerosol size distribution, but also the variability in $z_{0}$ and $z / L$.

The large surface elements on Aerosol Hill gave a median surface roughness height of $0.11 \mathrm{~cm}$, while the median surface roughness height at Lilla Vardet was $0.03 \mathrm{~cm}$. The median dry-deposition velocity was $>100 \%$ higher over the rougher surface than over the smooth surface at Lilla Vardet. A study by Schack and others (1985) consists of a number of windtunnel experiments over various surfaces, weighting the diffusion and interception effects with the empirical constants $A$ and $B$ (see Equation (7)). They report a surface that consisted of gravel in the $3.8-5.1 \mathrm{~cm}$ size range, which resulted in surface roughness heights of $0.3-0.6 \mathrm{~cm}$ and deposition velocities ranging from 0.05 to $33 \mathrm{~cm} \mathrm{~s}^{-1}$. The constants $A$ and $B$ for gravel were according to them $4.0 \pm 0.4$ and $121 \pm 8$, respectively. To calculate the quasi-laminar sub-layer resistance $r_{\mathrm{b}}$ at Aerosol Hill, the empirical parameters had to be approximately 10 times larger $(A=75, B=1000)$ to parameterize the median dry-deposition velocity.

Analysis of the DMPS data showed that there were three distinct particle-size modes in the sub-micron aerosol (Fig. 2). These number modes had a geometric mean diameter of around 14, 42 and $134 \mathrm{~nm}$, referred to as ultrafine, Aitken and accumulation-mode, respectively. This agrees approximately with the range found by Covert and others (1996) in the Arctic marine boundary layer. The data from the EC measurements at Aerosol Hill were divided into three different categories based on the aerosol number size distributions:

(a) ultrafine $\left(D_{\mathrm{p}}=10-20 \mathrm{~nm}\right)$ whenever there was an ultrafine mode present 
Table 4. Dry-deposition velocity $\left(\mathrm{cms}^{-1}\right)$ at Aerosol Hill for the three size categories ultrafine, Aitken, and Aitken plus accumulation, given as arithmetic mean plus or minus $1 \sigma$, the median, the range where $90 \%$ of the data are found and the number of data points (0.5 hour averages)

\section{Ultrafine Aitken Aitken plus accumulation}

\begin{tabular}{lccc}
\hline Mean $\pm \sigma$ & $1.29 \pm 1.17$ & $1.12 \pm 1.20$ & $0.92 \pm 1.38$ \\
Median & 1.02 & 0.75 & 0.40 \\
$90 \%$ range & $0.13-3.09$ & $0.34-2.28$ & $0.09-2.17$ \\
Number & 27 & 131 & 28 \\
$v_{\mathrm{d}}$ over sea ice* & 0.14 & 0.051 & - \\
\hline
\end{tabular}

*Nilsson and Rannik (2001).

(b) Aitken $\left(D_{\mathrm{p}}=20-90 \mathrm{~nm}\right)$ when there was an Aitken mode but no ultrafine or accumulation mode present; and

(c) Aitken plus accumulation (20 nm $\left.<D_{p}<200 \mathrm{~nm}\right)$ when both modes were present at the same time.

There were no cases with only an accumulation mode present. Nilsson and Rannik (2001) used a similar approach for the $v_{\mathrm{d}}$ over the Arctic Ocean pack ice and also could not separate a specific dry-deposition velocity for only accumulation-mode particles. Since Aitken mode was present most of the time, the third category could not consist of a pure accumulation mode but had to be a combination of both. This was also the case for the ultrafine mode, where an Aitken and an accumulation mode were also present. Since the measured $F$ includes a wide range of particle sizes, it is difficult to relate $v_{\mathrm{d}}$ to $D_{\mathrm{p}}$. The number of Aitken-mode particles may have dominated the category with the accumulation mode, while the number of ultrafine-mode particles probably dominated the category of ultrafine mode.

Median dry-deposition velocities to the snow-free surface at Aerosol Hill were 1.02, 0.75 and $0.40 \mathrm{~cm} \mathrm{~s}^{-1}$ for the ultrafine, Aitken and Aitken plus accumulation-mode category, respectively. These are larger than the values given by Nilsson and Rannik (2001) over sea ice (Table 4). The measured median dry-deposition velocity of each size category agrees with that calculated from Equations (5-7) with $A$ and $B$ set to 75 and 1000 , respectively, through empirical evaluation. Since we have tuned $A$ and $B$ in Equation (7) to fit the observations, the agreement between the magnitude of the measured and calculated $v_{\mathrm{d}}$ is not a solid result. However, the $\mathrm{d} v_{\mathrm{d}} / \mathrm{d} D_{\mathrm{p}}$ slope is much less influenced by the choice of $A$ and $B$ than is $v_{\mathrm{d}}$. The $\mathrm{d} v_{\mathrm{d}} / \mathrm{d} D_{\mathrm{p}}$ slope between the dry-deposition velocities of the ultrafine and Aitken modes as measured $\left(-0.7 \times 10^{5} \mathrm{~cm} \mathrm{~s}^{-1} \mathrm{~m}^{-1}\right)$ and given by Equations (5-7) $\left(-1.1 \times 10^{5} \mathrm{~cm} \mathrm{~s}^{-1} \mathrm{~m}^{-1}\right)$ agrees well. This is a confirmation from field data that indeed the small ultrafine-mode particles have a higher deposition velocity than the larger Aitken-mode particles, as predicted by theory, owing to a stronger Brownian diffusion.

\section{GONGLUSIONS}

The rate at which aerosol particles or gases deposit at the surface is affected by different physical and meteorological conditions, (e.g. surface structure, the level of atmospheric turbulence and physical and chemical properties of the depositing species). The factors that primarily affected dry-deposition velocity during the measurement period in January 2000 in
DML were the stratification of the surface boundary layer $(z / L)$, the surface albedo, the surface roughness height $\left(z_{0}\right)$ and the aerosol particle size $\left(D_{\mathrm{p}}\right)$.

The stratification of the surface boundary layer over the smooth, snow-covered area at Lilla Vardet with a high albedo was less unstable than over the snow-free, low-albedo, rocky surface at Aerosol Hill. The different conditions at the sites resulted in median dry-deposition velocities, for all particle sizes $\left(D_{\mathrm{p}}>10 \mathrm{~nm}\right),>100 \%$ larger at Aerosol Hill than at Lilla Vardet: 0.80 and $0.33 \mathrm{~cm} \mathrm{~s}^{-1}$, respectively. The diurnal variation in solar zenith angle caused diurnal variations in surface boundary-layer stability, temperature and fluxes. The diurnal variations were larger over the snow-free area than over the snowfield. An increase in friction velocity was observed when the stability diminished during the day.

The dry-deposition fluxes were dominated, in terms of number, by the ultrafine and Aitken modes since they were present and numerous most of the time and had larger drydeposition velocities than the accumulation mode. We were not able to isolate the flux of accumulation-mode or larger particles, and although we expect them to contribute less to the number concentration, their influence on the mass concentration in the ice may be large for some species. The median drydeposition velocities for the three size categories, ultrafine, Aitken, and Aitken plus accumulation mode, to the snowfree surface at Aerosol Hill were 1.02, 0.75 and $0.40 \mathrm{~cm} \mathrm{~s}^{-1}$, respectively. The $\mathrm{d} v_{\mathrm{d}} / \mathrm{d} D_{\mathrm{p}}$ slope between the dry-deposition velocities of the ultrafine and Aitken modes as measured and calculated agreed well.

To use dry-deposition velocities in the interpretation of icecore deposition records requires not only an understanding of the local meteorological conditions and their variations with time, but also better knowledge of the particle-size mode in which different species are deposited. This may also have changed between different climatic stages due to a changed matrix of the atmospheric aerosol.

\section{AGKNOWLEDGEMENTS}

This project was carried out as part of the Swedish and Finnish Antarctic Research Programmes (SWEDARP and FINNARP) 1999/2000. We thank the Swedish Polar Research Secretariat and the crews at Wasa and Aboa for logistic support during the field campaign. The Swedish Natural Science Research Council and the Finnish Academy are acknowledged for financial support, and Ü. Rannik for his help with the flux calculations. We would like to thank the Department of Physics at the University of Helsinki for lending us the ultrasonic anemometer, and the Institute of Applied Environmental Research at Stockholm University for lending us the CPC.

\section{REFERENCES}

Barnola, J. M., D. Raynaud, Ye. S. Korotkevich and C. Lorius. 1987. Vostok ice core provides 160,000-year record of atmospheric $\mathrm{CO}_{2}$. Nature, 329(6138), 408-414.

Bergin, M. H. and 8 others. 1995. The contributions of snow, fog, and dry deposition to the summer flux of anions and cations at Summit, Greenland. 7. Geophys. Res., 100 (D8), 16,275-16,288.

Buzorius, G., Ü. Rannik, J.M. Mäkelä, T. Vesala and M. Kulmala. 1998. Vertical aerosol particle fluxes measured by eddy co-variance technique using condensational particle counter. F. Aerosol Sci., 29(1-2), 157-171.

Buzorius, G., Ü. Rannik, J. M. Mäkelä, P. Keronen, T. Vesala and M. Kulmala. 2000. Vertical aerosol fluxes measured by the eddy co-variance method and deposition of nucleation mode particles above a Scots pine forest in southern Finland. f. Geophys. Res., 105(D15), 19,905-19,916. 
Cadle, S. H., J. M. Dasch and P. A. Mulawa. 1985. Atmospheric concentrations and the deposition velocity to snow of nitric acid, sulfur oxide and various particulate species. Atmos. Environ., 19(11), 1819-1827.

Covert, D. S., A. Wiedensohler, P. Aalto, J. Heintzenberg, P. H. McMurry and C. Leck. 1996. Atmospheric number distributions from 3 to $500 \mathrm{~nm}$ diameter in the Arctic marine boundary layer during summer and autumn. Tellus, 48B, 197-212.

Davidson, C. I., S. Santhanam, R. C. Fortmann and M. P. Olson. 1985. Atmospheric transport and deposition of trace elements onto the Greenland ice sheet. Atmos. Environ., 19(12), 2065-2081.

Davidson, C. I., M. H. Bergin and H. D. Kuhns. 1996. The deposition of particles and gases to ice sheets. In Wolff, E. W. and R. C. Bales, eds. Chemical exchange between the atmosphere and polar snow. Berlin, etc., Springer-Verlag, 275-306. (NATO ASI Series I: Global Environmental Change 43.)

Fuhrer, K., E.W. Wolff and S. J. Johnsen. 1999. Timescales for dust variability in the Greenland Ice Core Project (GRIP) ice core in the last 100,000 years. 7. Geophys. Res., 104(D24), 31,043-31,052.

Hansson, M. E. 1994. The Renland ice core: a Northern Hemisphere record of aerosol composition over 120000 years. Tellus, 46B(5), 390-418.

Hillamo, R. E., V.-M. Kerminen, W. Maenhaut, J.-L. Jaffrezo, S. Balachandran and C. I. Davidson. 1993. Size distributions of atmospheric trace elements at Dye 3, Greenland: 1. Distribution characteristics and dry deposition velocities. Atmos. Environ., Ser. A, 27(17-18), 2787-2802.

Hinds, W. C. 1982. Aerosol technology. New York, John Wiley and Sons.
Ibrahim, M., L. A. Barrie and F. H. Fanaki. 1983. An experimental and theoretical investigation of the dry deposition of particles to snow, pine trees and artificial collectors. Atmos. Environ., 17(4), 781-788.

Kaimal, J. C. and J.J. Finnigan. 1994. Atmospheric boundary layer flows: their structure and measurement. Oxford, etc., Oxford University Press.

Legrand, M. R., C. Lorius, N. I. Barkov and V. N. Petrov. 1988. Vostok (Antarctica) ice core: atmospheric chemistry changes over the last climatic cycle (160,000 years). Atmos. Environ., 22(2), 317-331.

Moore, C. J. 1986. Frequency response corrections for eddy correlation systems. Boundary-Layer Meteorol., 37, 17-35.

Nilsson, E. D. and Ü. Rannik. 2001. Turbulent aerosol fluxes over the Arctic Ocean. Part I. Dry deposition over sea and pack ice. F. Geophys. Res. 106, 32,125-32,138.

Schack, C. J., S. E. Pratsinis and S. K. Friedlander. 1985. A general correlation for deposition of suspended particles from turbulent gases to completely rough surfaces. Atmos. Environ., 19(6), 953-960.

Seinfeld, J. H. and S. N. Pandis. 1998. Atmospheric chemistry and physics: from air pollution to climate change. New York, John Wiley and Sons.

Steffensen, J. P. 1997. The size distribution of microparticles from selected segments of the GRIP ice core representing different climatic periods. 7. Geophys. Res., 102(C12), 26,755-26,763.

Unnerstad, L. and M. Hansson. 2001. Simulated airborne particle size distribution over Greenland during Last Glacial Maximum. Geophys. Res. Lett., 28(2), 287-290. 